\title{
TEOLOGIESE WEERBAARHEID AS KERKLIKE VEREISTE. ONS TEOLOGIESE OPLEIDING ONDER DIE LOEP
}

\author{
A B DU TOIT
}

\begin{abstract}
Theological preparedness as ecclesiastical requirement. Our theological training reconsidered

The theological and spiritual aspects of training for the ministry belong inseparably together. Likewise theological training and endowment by the Spirit should not be seen as alternatives, but as complementing each other. In order to identify the theological requirements for the ministry eight typical functions of a minister of the Word are discussed. The effective implementation of these functions is, however, greatly impeded by fundamental changes in modern society. This increases the responsibility of theological faculties. In conclusion tentative guidelines for a revised theological curriculum are presented.
\end{abstract}

\section{INLEIDENDE OPMERKINGS}

\subsection{Die term "weerbaarheid"}

Weens sy militêre konnotasies word bogenoemde term slegs gebruik by gebrek aan ' $n$ meer bevredigende benaming. In sy metaforiese spreke oor God en sy handelinge met mens en wêreld maak die Bybel egter ruimskoots van metafore uit alle lewensterreine gebruik, ook uit die militêre sfeer. Sowel die Ou Testament as die Vroeg-jodedom ken 'n lang tradisie van aanwending van oorlogsterme in religieuse verband. In hul verstrengeling met die idee van die "Heilige Oorlog" word hierdie terme heel konkreet bedoel; dikwels word hulle egter vergeestelik, met ander woorde metafories aangewend. Dit is deurgaans die geval in die Nuwe Testament waar die idee van die Militia spiritualis waarby elke Christen in sy stryd teen die Bose betrokke is, meermale voorkom." In die verband van hierdie aanbieding word die benaming "teologiese weerbaarheid" gebruik in die sin van die gespierde en omvattende teologiese toegerustheid en gereedheid van die jong predikant om die groot verskeidenheid van gewigtige eise wat die bediening aan hom stel, op effektiewe wyse tegemoet te tree. 


\subsection{Teologiese en geestelike weerbaarheid}

Teologiese en geestelike weerbaarheid mag onderskei - en selfs dit is soms onmoontlik - maar mag nooit van mekaar geskei word nie. Sodanige skeiding kan sowel vir die teologie as die geloofslewe van die predikant katastrofaal wees. 'n Teologie wat nie gekenmerk word deur'n ware geloof, 'n egte roepingsbewustheid, 'n innige vroomheid, met ander woorde deur' $n$ diepe spiritualiteit nie, is nie ware teologie nie. Dit is so steriel en futiel soos die doenighede van die musikoloog wat geen snars musiekaanvoeling het nie. Ware teologie is slegs moontlik vanuit ' $n$ eksistensiële aangryping deur die saak van die teologie, naamlik die vaste oortuiging dat God Hom in sy Woord op unieke wyse aan ons geopenbaar het. Andersom kan ware spiritualiteit slegs koers hou as dit deur die nodige teologiese insig, gerigtheid en geankerdheid gedra word. Wanneer hierdie twee onderwerpe dus afsonderlik aan die orde gestel word, gaan dit bloot om ' $n$ werksverdeling, nie om ' $n$ saaklike skeiding nie.

\subsection{Teologiese opleiding en die gawes van die Gees}

In sy oorsig oor die historiese ontwikkeling van die predikante-opleiding maak Frick ten opsigte van die vroeë kerk die stelling: "Die entscheidende Voraussetzung für jedes Amt in der christlichen Gemeinde war die charismatische Begabung. Das schliesst aber eine menschliche Zurüstung durch die persönliche Bindung eines Schülers an den Meister nicht aus." "2) Hiermee het Frick ten spyte van sy versigtige formulering, in feite die teologiese in-diens-opleiding - want dit was dit tog in wese - van die eerste ampsdraers ondergeskik gestel aan hul Geestesgawes. Daarmee verval hy tog maar weer in Sohm se eensydige verabsolutering van die eksklusiewe belangrikheid van die charismata. Die evangelies en die Nuwe-Testamentiese briewe lê egter soveel klem op die regte onderrig en leer (vgl reeds Jesus se intensiewe dissipelonderrig) dat charismatiese toerusting en onderrig in die regte leer nie teen mekaar uitgespeel mag word nie. Die apostels is immers deur Jesus onderrig en hulle het die Geestestoerusting ontvang. Die beoefening van die gawes moes steeds deur die regte "teologie" gelei en gekanaliseer word. Die ontvangs van die gawes het nie op sigself die instorting van ' $n$ bepaalde volume teologiese insig beteken nie. Ons kan nog verder gaan en vermoed dat gawes en "teologie" mekaar wedersyds aangevul en gestimuleer het. Ons kan moeilik anders as om te aanvaar dat byvoorbeeld 'n gawe soos die onderskeiding van geeste juis deur groei in teologiese insig verder aangewakker en uitgebou sou word. Geestes- 
begiftiging en teologiese opleiding skakel mekaar dus geensins uit nie, maar veronderstel mekaar en vul mekaar aan.

1.4 Ons gaan nou eerstens aandag gee aan die teologiese eise wat die bediening aan ' $n$ predikant stel en aan die faktore wat voldoening aan hierdie vereistes in ons moderne tyd bemoeilik. Vervolgens gaan ek enkele riglyne probeer gee ten opsigte van die wyse waarop teologiese fakulteite kan poog om teologiese studente beter op hierdie vereistes voor te berei.

\section{DIE TEOLOGIESE EISE WAT DIE MODERNE BEDIENING AAN 'N PREDIKANT STEL}

\subsection{Die teologiese eise wat die verskillende funksies van predikantwees aan die leraar stel}

2.1.1 Die omvattendheid van die rolverwagting ten opsigte van 'n predikant in ons samelewing is sodanig dat dit onmoontlik deur middel van die identifisering van ' $n$ aantal tipiese teologiese of ander funksies omskryf kan word. Die geheel is altyd groter as die somtotaal van sy dele. Daarby kan die teologiese en ander funksies nie alleen nooit netjies van mekaar geskei word nie, maar oorvleuel onderling op talle wyses. Die identifisering van 'n aantal noodsaaklike funksies wat hieronder volg, is in vele opsigte onvoldoende en onbevredigend. Hulle kan nietemin 'n idee gee van die omvang en aard van die eise waaraan die bediening moet voldoen.

\subsubsection{Enkele noodsaaklike primêr teologiese funksies van die predikant}

\section{(a) Die hermeneutiese funksie}

Die leraar is die man van God wat in die spanningslinie tussen God en mens moet staan. "Was tunst du, du Mensch, mit Gottes Wordt auf deinen Lippen?"' is die vraag van Karl Barth ${ }^{31}$ wat elke ernstige bedienaar van die Woord telkens weer aan homself moet stel. Die belangrikheid van die predikant se hermeneutiese funksie blyk uit die feit dat iemand soos $G$ Ebeling selfs die geheel van die teologiese kurrikulum vanuit die hermeneutiese gesigspunt kon omskryf.") Om 'n ware hermeneut te wees wat God se Woord, soos gekontekstualiseer in Bybelse literatuurvorme en kultuur-historiese omstandighede, op 
geslaagde wyse vir mense van ons tyd in hulle spesifieke kultuurvorme en omstandighede te kan herkontekstualiseer, moet die predikant aan drie vereistes beantwoord: eerstens moet hy die Skrif deeglik ken en eksegeties kan ontsluit; tweedens moet hy die mens en die strominge van sy eie tyd ken en verstaan; en derdens moet hy oor die vermoë beskik om wat hy uit die Woord verneem het, op 'n bevatlike, sinvolle en appellerende wyse aan hierdie mense oor te dra. Met "bevatlik" word bedoel dat hy nie die boodskap agter ' $n$ barrikade van hoogdrawende en onverstaanbare terme mag verberg nie - bes moontlik omdat hy self nog nie goed verstaan het waarom dit gaan nie. Met "sinvol" word bedoel dat hy nie alleen die juiste boodskap vir die spesifieke behoefte van sy gemeente sal oordra nie, maar dit ook op 'n logiese en geordende wyse sal doen. En met "appellerend" word bedoel dat dit op so 'n manier sal geskied dat dit sy hoorders persoonlik sal aanspreek en opeis - wat natuurlik slegs sal kan gebeur as hyself persoonlik aangespreek en opgeëis is. Vir hierdie bevatlike, sinvolle en appellerende oordrag sal hy helder en logies moet kan dink, treffend moet kan formuleer en selfs oor 'n mate van oorspronklikheid en kreatiwiteit moet beskik.

\section{(b) Die liturgies-homiletiese funksie}

Die erediens is die sentrale en beslissende ontmoetingsgebeure tussen God en sy gemeente, die naaf waar alle gemeentelike en koninkryksbedrywighede mekaar ontmoet en so gesamentlik hulle koers en vastigheid rondom die stewige as van die Woord vind. Daarom moet die bedienaar van die Woord by uitnemendheid iemand wees wat die liturgiese geheim verstaan en dit aan die aanbiddende en luisterende gemeente kan oordra. Wie nie die fyn kuns van liturg en homileet-wees verstaan en voldoende bemeester het nie, sal steeds ' $n$ tweederangse Verbi Divini Minister bly.

\section{(c) Die pastorale funksie}

Die herderlike funksie van die predikant vereis dat hy die vele behoeftes, probleme en krisisse van lede van die kudde wat aan hom toevertrou is, op so ' $n$ wyse op persoonlike vlak of in groepsverband sal hanteer dat die omvattende heil van die gelowiges en die opbou van Christus se gemeente daardeur gedien sal word. Hiervoor is onder meer ' $n$ basiese kundigheid ten opsigte van sekere insigte en reëls van die sielkunde en van die teorie en praktyk van die pastorale gesprek in sy wye verskeidenheid absoluut noodsaaklik. 
Deur alle eeue was daar ' $n$ opvoedkundig-didaktiese funksie aan die amp verbonde. Reeds in Bybelse tye het dit uitvoerige aandag geniet. Dink maar aan die groot klem hierop in die boeke van die Pentateug, in die wysheidsliteratuur, die Matteusevangelie, en die Pastorale Briewe. Met die indrukwekkende ontwikkeling van die opvoedkunde in die afgelope dekades het die kerk al hoe meer bewus geword van die belangrikheid en die veeleisendheid van hierdie dimensie van sy werk - nie net wat sy kategetiese roeping betref nie, alhoewel op besondere wyse ook daar, maar veral ook in sy omvattende jeugbearbeiding.

\section{(e) Die missionêre funksie}

As dit so is dat die apostolaat ' $n$ wesensfunksie van die kerk is, en in die lig van die Skrif staan dit soos ' $n$ paal bo water, mag geen predikant, ook nie diegene wat in 'n gevestigde, oënskynlik reeds gekerstende gemeenskap staan, hulle aan die kerk se missionêre roeping onttrek nie. Afgesien daarvan dat die besondere ampte en gemeente ten opsigte van hulle tradisionele missionêre taak voorberei en toegerus moet word (volgens die ondersoeke van ISWEN is daar immers op hierdie gebied nog ontsaglik veel te doen), moet meer intensief aandag gegee word aan ons groeiende missionêre taak in die gevestigde a-Christelike blanke gemeenskap in ons midde. Om hier nog terminologies te wil onderskei tussen sending en evangelisasie is onsinnig en soms bloot 'n oorgeblewe stuk tradisie. Dit gaan in albei gevalle om mense wat die ware evangelie nie ken of verstaan, en wat daarmee bereik moet word nie.. ${ }^{5}$ Die aard van hierdie bereiking sal uiteraard verskil na gelang van diegene wat met die evangelie gekonfronteer moet word. Dit alles maak die predikant se missionêre taak geweldig belangrik, selfs al word hy nie sendeling in die tradisionele sin nie.

\section{Die divinatories-gubernetiese funksie}

Die Woordeboek van die Afrikaanse Taal noem as derde noempotensie van die term "divinasie" die "godsdienstige kenvermoë". Ek gebruik die woord "divinatories" hier in die sin van die vermoë om die dieperliggende aard van gebeure, geestesstrominge en die talle ander verskynsels waarmee ons mense, ons kerke en ons samelewing gekonfronteer word, vanuit openbaringsperspektief suiwer na hulle ware aard te onderken en 
positief of negatief te "ontmasker". Dit gaan hier om die onderskeiding van die geeste, 'n gawe wat ongetwyfeld onder die werking van die Gees deur teologiese skoling en ervaring geoefen en uitgebou moet en kan word. Om die eietydse strominge en historiese gebeure na hulle diepste wese sub specie Dei te onderskei en aan die volk van God leiding te gee, was een van die basiese funksies van die Bybelse profete. Dit was ook een van die onontwykbare verantwoordelikhede van die amp deur die eeue. Die leraar sal toegerus moet wees om nie slegs algemene geestesbeweginge van sy tyd soos die materialisme, sekularisme, humanisme, Marxisme en hedonisme in hulle menigvuldige subtiele en minder subtiele gestaltes suiwer te onderskei en leiding daaromtrent te gee nie, maar ook die talle ander tendensies wat op die denke en beleweniswêreld van ons mense, veral ook van ons kinders en jongmense, hulle merk laat. Dink maar net hoe blootgestel ons huisgesinne aan die televisie is en aan allerlei onrusbarende tendensies wat daar na vore tree. Hoeveel leiding word van kerklike kant in hierdie verband gegee? Onlangs is 'n nuwe casino digby Pretoria geopen. Hoeveel daadwerklike en sinvolle leiding word ten opsigte van hierdie saak gegee? Blote afwysings is nie genoeg of selfs oortuigend nie. Goed verantwoorde stellingnames is nodig. So alleen sal ons binne kerklike sowel as koninkryksperspektief sinvolle leiding aan ons politici, medici, juriste, opvoedkundiges, kunstenaars, militariste, kortom aan al ons mense, ontwikkeld en onontwikkeld, kan gee.

\section{(g) Die verantwoordingsfunksie}

Die kerk is onherroeplik betrokke by die stryd om die waarheid. Die rekenskap gee van die "waarom", die "wat" en die "waartoe" van ons geloof bly een van ons basiese verantwoordelikhede. Dit is nie verniet dat gelowiges in 1 Petrus 3:15 opgeroep word om altyd gereed te wees om aan elkeen rekenskap te gee van die hoop wat in hulle is nie. Geloof is steeds ' $n$ gawe van God en kan nie deur logiese redenasies opgewek word nie, maar ons kan Anselmus se credo ut intellegam nooit van ons afskud as ons verantwoordelik met die teologie omgaan nie. Ek wil hoegenaamd nie beweer dat die Christelike geloof logies bewys kan word nie, wel egter dat die fundamenteel-teologiese vrae na die sinvolheid en die waarheidskarakter, na die integriteit en logiese struktuur van ons geloof en van die teologie opnuut in alle duidelikheid gevra sal moet word. Hierop het Wentzel van Huyssteen ${ }^{6)}$ in sy jongste en uiters belangrike werk opnuut die aandag gevestig. Ons is dit aan onsself, aan ons eie ernstig denkende, soekende, vraende mense verskuldig. Ons sal 
die ou "friss Vogel oder stirb"-benadering") ("my boetie, jy moet maar hierdie dinge glo anders gaan jy pylreguit verderf toe") moet afskud. Daar sal grondig op ons mense se intellektuele en aanverwante probleme ingegaan moet word. Jowett het die gevleuelde woord gespreek:

Doubt comes in at the window

When inquiry is denied at the door.

Ook hierdie verantwoordingsfunksie is niks nuuts vir die kerk nie. Reeds die apologete van die tweede eeu, die kerkvaders en die reformatore het daarvan geweet. Dit spreek vanself dat hierdie selfverantwoording ook ten opsigte van die ander godsdienste soos byvoorbeeld die Judaïsme en die Islam, noodsaaklik is.

Dit is wel so dat ons nou nog nie ten volle ken nie, dat ons 'n "raaiselagtige beeld" in 'n "dowwe spieël" sien (1 Korinthiërs 13:12), maar dit neem nie weg nie dat ons van harte glo dat die spieël tog aan ons reeds die beslissende buitelyne van die werklikheid toon, dat ons deur die universele waarheid gegryp is en onderweg is na die ten voile ken en verstaan. Daarom moet ons meedoen aan die stryd van die geeste en ons nie aan die stryd om die waarheid onttrek nie. ${ }^{8)}$

\section{(h) Die bestuursfunksie}

In ooreenstemming met die Skrif wat die amp as 'n diens beskou, ken ons Gereformeerde ampsbeskouing geen hiërargie in die kerk nie. Dit neem egter die feit nie weg dat die predikant 'n uiters belangrike bestuursfunksie in die gemeente en ook in meerdere vergaderings het nie. Hy moet derhalwe nie alleen goed op die hoogte wees van die beginsels en praktyk van bestuur nie, maar ook van ons kerkreg.

\subsection{Enkele eietydse faktore wat voldoening aan bogenoemde vereistes bemoeilik}

\subsubsection{Die rolverandering van die predikant in ons samelewing}

Vroeër, in sommige gevalle selfs tot heel onlangs, het die predikant 'n besondere patriargale rol in ons gemeenskap gespeel. Hy was die geestelike en dikwels ook die intellektuele leier en mentor, meermale ' $n$ soort ensiklopediese "all-rounder" wie se woord selde, behalwe miskien in die verborgenheid van enkele brawe harte, bevraagteken is. Vandag is ons wêreld vol spesialiste wat elk op sy eie gebied en dikwels ook op 
ander gebiede meer weet as die predikant. Meermale is hulle intellektueel die dominee se meerdere. Ook die boer, die bouer, die sakeman is ' $n$ spesialis op eie terrein. Die leraar is teruggedring tot op sy eie teologiese en geestelike werf. Maar ook daar word hy getoets en moet sy optrede Skrifgetrou, verantwoord en oortuigend wees. ' $n$ Sukkelaar of geestelike naaldekoker mag nog miskien in stilte geduld word, maar die saak van die koninkryk ly ontsettend skade. Die teologiese en geestelike kwaliteit van ons bediening word voorwaar getoets soos nog nooit tevore nie.

\subsubsection{Die veranderde karakter van ons moderne samelewing}

Waar ons samelewing vroeër redelik homogeen was en die Christelike waardes vry probleemloos as norm aanvaar is, het ons moderne samelewing oneindig toegeneem in verskeidenheid en kompleksiteit. Die veeltal standpunte, strominge en groepe, asook politieke groeperinge wat op ons mense se gees beslag wil lê, bring grootskaalse verwarring en onsekerheid. Waar ons gemeenskap voorheen 'n sterk sekerheidsinslag gehad het (ons het ten regte of ten onregte duidelik geweet wat is reg en wat is verkeerd - vergelyk maar ons Sondagbeskouingl, word ons huidige samelewingsingesteldheid al hoe meer onseker, relatiwisties en permissief. Instellings soos die huwelik word bevraagteken. Ons word gekonfronteer met steeds aggressiewer homoseksuele groepe. Ons lees van allerlei dinge wat op ons strande gebeur. Ons skoolgaande kinders plaas ons voor probleme wat in ons eie tyd ongekend was. Daarbenewens plaas die tempo, die hoë eise, die verwarring en ook die dekadensie van ons tyd mense onder soveel druk dat die menslike gees dit nie meer kan verwerk nie en meegee. Depressie en allerlei senusiektes is aan die orde van die dag. Die pastorale eise wat aan die moderne predikant gestel word, is met een woord geweldig.

\subsubsection{Ongekende blootstelling deur middel van die media}

Deur middel van die moderne, hiperverfynde kommunikasiemedia word predikante se uitsprake nie maar in 'n hoekie gefluister nie. In 'n verskeidenheid van rubrieke en programme word hulle deur duisende gelees, weerklink hulle in huise, motors, hospitale, militêre bunkers. 'n Dominee se onsigbare publikum is dikwels honderdvoudig groter as sy sigbare. Sy standpunte word in plekke ingedra wat hy nooit sou kon vermoed het nie. Hierdie is voorheen ongekende geleenthede, maar die verantwoordelikheid, veral voor 'n ongenadige medium soos die televisiekamera, het dienooreenkomstig groter geword. 


\section{ENKELE RIGLYNE TEN OPSIGTE VAN DIE WYSES WAAROP TEOLOGIESE FAKULTEITE ' $N$ BYDRAE KAN LEWER OM VOORNEMENDE PREDIKANTE OP BOGENOEMDE VEREISTES VOOR TE BEREI}

3.1 Om teologiestudente enigsins op bogenoemde vereistes voor te berei is 'n omvattende en haas onbegonne taak. Veel hiervan sal inderdaad eers in die bediening self bygebring kan word. Ek kan in hierdie verband nie meer doen as om vry selektief te werk en slegs enkele riglyne te probeer gee nie. Ek sal nie die positiewe herhaal wat reeds verrig word nie, behalwe om te sê dat ons, terugskouend oor die 50 jaar van ons fakulteit se bestaan, innig dankbaar is vir die wyse waarop die Here ons eie fakulteit, saam met die ander fakulteite van ons kerk, tot hiertoe in sy diens gebruik het. Ek dink dit sal sinvoller, vrugbaarder en vir 'n lid van die dosentekorps van hierdie fakulteit meer gepas wees om te wys op sekere behoeftes waaraan na my mening besondere aandag gegee sal moet word. Dit sal my ook seker nie verkwalik word as ek enkele spesifieke verwysings na ons eie fakulteit maak nie.

3.2 Vanweë die steeds groeiende eise wat aan ons teologiese opleiding gestel word, kan 'n weldeurdagte, gebalanseerde keuringsproses myns insiens nie langer uitgestel word nie. Verskillende nie-teologiese fakulteite pas reeds keuring toe en dit gaan blykbaar steeds meer aan die universiteite die geval word. Die beginsel van keuring op grond van persoonlikheidsfaktore is reeds jare gelede deur ons kerk aanvaar ${ }^{9)}$ en die jongste sinode het opdrag gegee dat die kwessie van keuring ondersoek moet word. ${ }^{10)}$ Hierdie keuringsproses sal deurlopend moet wees en aan alle relevante vereistes vir die bediening aandag moet gee en nie net aan akademiese potensiaal nie. Dit spreek egter vanself dat laasgenoemde 'n belangrike vereiste sal moet wees sodat ons studente die mas ten opsigte van die eise van die bediening sal opkom. Dit is om hierdie rede dat die kwessie van keuring op die oomblik die ernstige aandag van ons kuratoria geniet.

3.3 Met die oog op die leraar se hermeneutiese funksie sal meer as ooit op kennis van die grondtale, op kennis van die Skrif en sy eie besondere karakter en op vaardigheid in die eksegetiese metodiek gekonsentreer moet word. Ons eie universiteit het nog al die jare oor uitstekende departemente in Semitiese Tale en Grieks beskik en staan in 'n uitmuntende eksegetiese tradisie wat vir altyd veral aan die pionierswerk van prof E P Groenewald verbind sal bly. In die afgelope jare is besondere aandag aan die eksegetiese metodiek gegee. Dit het egter 
toenemend duidelik geword dat die konkrete Bybelkennis van ons studente nie altyd voldoende is nie. Aan die einde van hulle studietydperk kan hulle soms meer oor die Bybel as uit die Bybel praat. In die intensiewe herkurrikuleringsproses waarmee ons op die oomblik besig is, word intensief aan hierdie leemte aandag gegee. Die wysheid van die Bibelkunde-program van Duitse teologiese fakulteite word al hoe duideliker ingesien. Ons hermeneutiese taak vereis egter ook, soos reeds aangedui, 'n grondige kennis van die moderne mens en wêreld en sy eietydse tendensies en strominge. ${ }^{11}$ Hoewel reeds hieraan in verskillende departemente aandag gegee word, sal nog intensiewer op hierdie behoefte gekonsentreer moet word. Studente openbaar meermale ' $n$ soort piëtistiese wêreldvreemdheid of gaan andersins onversteurd met oogklappe deur alles heen. Die tendensies en geestestrominge van ons dag gaan onopgemerk aan hulle verby.

Die koms van die geïntegreerde teologiese kursus het vir ons teologiese studie geweldige winspunte gebring en ons sal nooit weer na die ou bedeling wil terugkeer nie. Vir sy volhardende baanbrekerswerk om hierdie saak te verwerklik sal ons prof $\mathrm{A} \mathrm{H}$ van $\mathrm{Z} y \mathrm{l}$ altyd dankbaar bly. Vanweë die groot behoefte in hierdie verband en ook vanweë die feit dat die huidige kursus onvermydelik ' $n$ mate van verskraling ten opsigte van studente se kennis van die humaniora en derhalwe van die mens en die groot geestestrominge van ons tyd inhou, moet in die teologie self nou meerdere voorsiening vir hierdie behoefte gemaak word.

Bogenoemde behoefte geld ook kennis van en blootstelling aan die teologiese strominge van ons tyd. So byvoorbeeld was dit vir baie van ons destyds tot ontsaglike voordeel dat prof A B du Preez sy studente, ten spyte van die negatiewe houding van die Gereformeerde wêreld, aan die teologiese denke van Karl Barth blootgestel het.

Alleen deur middel van ' $n$ deeglike kennis van ons eie tyd en al sy belangrike teologiese en ander denkpatrone sal ons ons hermeneutiese taak, maar ook ons divinatories-gubernetiese en verantwoordingsfunksies, behoorlik kan behartig.

3.4 Wat die verantwoordingstaak betref, is ek van mening dat in hierdie opsig veel meer gedoen kan word, nie in die sin van 'n negatiewe verdedigende Fundamentaltheologie of die ou Apologetiek nie, maar in die $\sin$ van 'n konstruktiewe, geloofwaardige, wetenskaplik-kritiese rekenskapaflegging van die grondslae en wese van ons Christelike geloofsoortuigings. In ons moderne denkende, dikwels kritiese en soms selfs skeptiese samelewing is hierdie ' $n$ wesenlike behoefte.

3.5 Ten opsigte van die inrigting van kursusse word dit steeds 
duideliker dat dit onmoontlik is om al of selfs die grootste gedeelte van die relevante stof binne die tydperk van ses jaar in te pas. Belangrike aanvulling sal deur ' $n$ moontlike vikariaat, in die leerskool van die bediening en deur middel van konferensies en voortgesette teologiese opleiding moet geskied. Dit is bitter jammer dat daar nog steeds by sommige leraars 'n negatiewe houding of passiwiteit ten opsigte van veral laasgenoemde bestaan. Waarskynlik die belangrikste van alles is egter dat ons wordende predikante geïnspireer moet word om soos Friedrich Schleiermacher, lewenslank studente in die teologie te bly.

Om egter tot die inrigting van die teologiese studie self terug te keer: Die noodsaaklike beperking op die studievolume kan sinvol op drie maniere geskied: Eerstens deur op die beslissende, grondliggende uitgangspunte, beginsels en norme te konsentreer wat later self op die wisselende bedieningsomstandighede toegepas kan word. As studente byvoorbeeld werklik die wese van die erediens en die beginsels wat daar geld, begryp het is ' $n$ groot aantal rigiede, onveranderlike en gedetailleerde voorskrifte oor die verloop en elke onderafdeling van die erediens, kompleet met vasstaande Skriftekste, onnodig. Die leraar sal dan self weet hoe om, na gelang van wisselende omstandighede, hierdie beginsels in die erediens tot hulle reg te laat kom. Tweedens kan oorsigaanbiedings waarin die hoof kontoere getrek en die groot teologiese wetmatighede aangedui word sonder dat studente met 'n massa detail opgesaal word, van groot waarde wees. Wanneer nodig en toepaslik sal hulle dan wel die raamwerk hê waarbinne die detail sinvol ingevul kan word. Derdens kan paradigmaties gewerk word: Aan die hand van goedgekose voorbeelde, byvoorbeeld in die eksegese of in die etiek, kan studente leer om dieselfde werkwyse op ander soortgelyke gedeeltes of probleme te gaan toepas sonder dat alles in die fakulteit self aan die orde gestel word.

3.6 'n Ernstige probleem as gevolg van die skoolse wyse waarop akademiese studie nog steeds benader word, is studente se onvermoë om werklik selfstandig te dink, kreatief-krities te werk te gaan en, daarmee gepaardgaande, hulle insigte in helder geformuleerde vorm aan te bied. Hierdie vermoëns kan egter ontwikkel word deur middel van seminaarwerk, klasbesprekings, sinvol gekose werkopdragte en lesings wat selfstandige denke stimuleer. As 'n student eenmaal deeglik geleer het om 'n saak krities-analities tot op die been te analiseer, die probleem suiwer te diagnoseer en antwoorde en oplossings kreatief vanuit en in ooreenstemming met Skrif en belydenis te genereer, sal hy dit ook in die bediening kan doen. 
4. Na alles wat gesê is, bly dit 'n onomstootlike feit dat selfs die beste teologiese opleiding en die ernstigste insette van die kerk ter wille van ons teologiese opleiding tot mislukking gedoem is as diegene wat hulle tot die bediening geroepe voel, nie bereid en gemotiveerd is om alles in te sit ter wille van Christus se kerk en die koninkryk nie. Die opdrag aan Timoteus (2 Tm 2:15): "Lê jou daarop toe om jou tot beskikking van God te stel as ' $n$ arbeider wat die goedkeuring van God wegdra, 'n arbeider wat hom vir sy werk nie hoef te skaam nie, wat die woord van die waarheid suiwer verkondig", behoort die persoonlike votum van elke wordende evangeliedienaar te word. Dit is juis hierdie kombinasie, enersyds van blye vooruitsien na die "mooi so!" van die Meester, andersyds van bange huiwering om dalk eendag vanweë brouwerk bloedrooi van skaamte voor Hom te moet staan wat, uit liefde en dankbaarheid, ons dring om ons allerbeste te gee vir Hom wat ons eerste liefgehad en sy Allerbeste, die Seun van sy liefde, vir ons gegee het.

\section{NOTAS}

1. Die onderwerp van geestelike oorlogvoering in die kerkgeskiedenis word breedvoerig behandel deur A von Harnack, Militia Spiritualis. Die christliche Religion und der Soldatenstand in den ersten drei Jahrhunderten, Darmstadt 1963, 133-162.

2. In sy artikel "Pfarrervorbildung und -weiterbildung", RGG (herausgegeben von K Galling). Tübingen ${ }^{31957 f f, ~} \vee$ kolom 293.

3. Karl Barth, "Not und Verheissung der christlichen Verkündigung", in Das Wort Gottes und die Theologie, München 1925, 118. Elke predikant behoort ten minste eenmaal in sy lewe hierdie opstel van Barth oor die wese van die prediking te lees.

4. Vgl, om maar net een voorbeeld te gee, G Ebeling, "Hauptprobleme der protestantischen Theologie in der Gegenwart", ZThK 58(1961), 135.

5. Ek dink dus nie hier aan die kerklos lidmate wat wel die evangelie ken maar daarvan vervreemd geraak het nie. Hulle kan nog deur die gewone pastorale arbeid van die ampte bereik word. Ons sou hier wel van "herevangelisering" kon praat.

6. JW V van Huyssteen, Teologie as kritiese geloofsverantwoording: Teorievorming in die sistematiese teologie, RGN-Studies in Navorsingsmetodologie (reeksredakteur: Johann Mouton), Pretoria 1986.

7. H Zahrnt, Es begann mit Jesus von Nazareth. Die Frage nach dem historischen Jesus, Stuttgart 1960, 16.

8. Vgl ook J R Gray, "Theological training and parish work", in Ministers for the 1980's (edited by J Stein), Edinburgh 1979, 34 in verband met die baie vrae van lidmate. Kyk ook die belangrike opmerkings van W D Jonker ten opsigte van die stryd om die waarheid in meer beperkte sin, naamlik om die suiwerheid van die teologiese denke self, in sy artikel "Die predikant as teoloog", in: Bediening en Bedienaar. 'n Huldigingsbundel opgedra aan prof $J L$ de Villiers (saamgestel deur H J B Combrink, B C Lategan en B A Müller), Kaapstad 1987, 29-30.

9. Acta 1982, 1235.

10. Vgl Acta 1986, 632.

11. Tereg beklemtoon deur W D Jonker, a art, 23, 26-27. 